\title{
DUKUNGAN KELUARGA TERHADAP MOTIVASI LANJUT USIA DALAM MENINGKATKAN PRODUKTIFITAS HIDUP MELALUI SENAM LANSIA
}

\author{
Atikah Pustikasari $^{1)}$, Rima Restiana ${ }^{2)}$ \\ Program Studi D-III Keperawatan Universitas Mohammad Husni Thamrin \\ Atikah.pustikasari@yahoo.com
}

\begin{abstract}
ABSTRAK
Dukungan keluarga merupakan suatu bentuk perilaku melayani yang dilakukan oleh keluarga baik dalam bentuk dukungan emosional, penghargaan/penilaian, informasional dan instrumental. Dukungan keluarga merupakan salah satu unsur yang dapat memotivasi lansia yg ada dikeluarga untuk melakukan kegiatan, salah satunya adalah Senam lansia. Tujuan penelitian ini adalah Untuk mengetahui adanya hubungan dukungan keluarga terhadap motivasi lansia untuk mengikuti senam . Metode yang digunakan adalah analisis deskriptif dengan desain cross-sectional. Sampel digunakan total Sampling . Dukungan keluarga sangat penting dalam meningkatkan motivasi lanjut usia sehingga lanjut usia tetap produktif dalam kegi ganyang diberikan oleh keluarga sehingga motivasi lanjut usia untuk mempertahankan produktifitasnya sangat kurang, walaupun demikian tetap memberikan penghargaan kepada keluarga yang telah berusaha memberikan dukungan walaupun hanya berupa dukungan meterial. Dengan demikian diharapakan kepada pihak terkait seperti petugas kesehatan lebih sering lagi memberikan pendidikan kesehatan kepakeluarga , sehingga keluarga dapat memberikan dukungan baik dukungan penilaian, intrumental, informasi dan emosi . Dukungan berbagai dukungan yg diberikanoleh keluarga dapat meningkatkan motivasi lania untuk tetap pruduktif untuk mempeertahankan kesehatannya.
\end{abstract}

Kata Kunci: Dukungan keluarga, Motivasi, Lanjut usia.

\section{PENDAHULUAN}

Lansia merupakan seseorang yang usianya 60 tahun ke atas, baik pria maupun wanita. Menurut Departeman kesehatan RI menyebutkan bahwa dikatakan lanjut usia dimulai dari usia 55 tahun keatas. Menurut Badan Kesehatan Dunia (WHO) usia lanjut dimulai dari usia 60 tahun (Kushariyadi, 2010; Indriana, 2012). Berdasarkan data proyeksi penduduk, di prediksikan jumlah penduduk lansia tahun 2020 (27,08 juta), tahun 2025 (33,69 juta), tahun 2030 (40,95 juta) dan tahun 2035 (48,19 juta) (Kemenkes, 2017). Sedangkan jumlah lansia perempuan yaitu 10,77 juta lansia dan lansia laki-laki berjumlah 9,47 juta lansia (BPS, 2014).

Meningkatnya penduduk lanjut usia dibutuhkan perhatian dari semua pihak dalam mengantisipasi berbagai permasalahan yang ada. Penuaan penduduk membawa berbagai implikasi baik dari aspek social, ekonomi, hukum, politik dan terutama kesehatan (Komnas Lansia 2010). Meningkatnya populasi lansia ini tidak dapat dipisahkan dari masalah kesehatan yang terjadi pada lansia, menurunnya fungsi organ memicu terjadinya berbagai penyakit degenerative.

Salah satu upaya yang dapat dilakukan untuk mengurangi masalah kesehatan yang disebabkan karena proses menua yaitu dengan Senam lansia, yang merupakan salah satu alternatif yang posisitif untuk membina kesehatan jasmani dan memelihara kebugaran. Senam lansia selain memiliki dampak posisif terhadap peningkatan fungsi organ tubuh juga berpengaruh dalam meningkatkan imunitas dam tubuh manusia setelah latihan teratur. Senam lansia sendiri mempunyai banyak manfaat bagi lansia. Manfaat dari aktifitas olahraga ini 
akan membantu tubuh tetap bugar dan segar karena melatih tulang tetap kuat, mendorong jantung bekerja secara optimal, dan membantu menghilangkan radikal bebas yang ada di dalam tubuh (widianti \& atikah , 2010). Banyak lansia yang tidak mau mengikuti senam lansia disebabkan karena orang tersebut tidak atau belum tahu manfaat dari senam lansia. Serta kurangnya motivasi dari diri individu itu sendiri maupun dukungan dari keluarga yang kurang.

Faktor yang dapat mempengaruhi kurangnya motivasi lansia dalam mengikuti senam lansia yaitu kurangnya promosi kesehatan menyebabkan lansia cenderung tidak aktif dalam senam lansia dibandingkan dengan lansia yang didukung oleh promosi kesehatan (Indrawati, 2013). Faktor lain yang ikut mempengaruhi ketidakaktifan lansia adalah masalah waktu senam yang diadakan pada pagi hari dimana pada jam-jam tersebut lansia mempunyai aktivitas sendiri dirumah seperti mencuci baju atau membantu memasak (Paryanti, 2011). Perawat memberikan bantuan atau pembinaan terhadap kegiatan posyandu lansia dengan memberikan promosi kesehatan, penyuluhan serta bekerja sama dengan tokoh masyarakat untuk menggerakan lansia aktif datang mengikuti senam lansia. Perawat sebagai tenaga kesehatan hendaknya berkolaborasi dengan keluarga lansia agar memberikan motivasikepada lansia agar mau ikut dalam senam lansia. Dukungan keluarga merupakan tindakan yang paling penting dilakukan mengingat keluarga adalah orang dekat lansia yang biasa berinteraksi. Dukungan tersebut tentu akan memberikan stimulus bagi lansia untuk giat mengikuti senam lansia. Dari data yang diperoleh di posyandu lansia dari 89 lansia yang terdaftar, 18 sampai 30 orang yang aktif mengikuti senam lansia tiap kali dalam kegiatan senam yang dilakukan setiap minggunya di posyandu. (Azizah, 2011).

Dukungan keluarga adalah suatu bentuk perilaku melayani yang dilakukan oleh keluarga baik dalam bentuk dukungan emosional,penghargaan/penilaian, informasional dan instrumental (Friedman, 2010 dalam Yenni 2011). Stategi preventif yang paling baik untuk meningkatkan dukungan keluarga yang adekuat dalam membantu anggota keluarga dalam mempertahankan kesehatan. Keluarga yang baik akan memberi pengaruh positif bagi perkembangan lansia, dan sebaliknya (Handayani \& Wahyuni, 2012). Rendahnya dukungan keluarga akan mempengaruhi perilaku lansia dalam pemeliharaan kesehatan dan akan berdampak pada penurunan kualitas hidup lansia Bila lansia mendapat dukungan yang cukup dari keluarga, maka lansia akan termotivasi untuk merubah perilaku untuk menjalani gaya hidup yang sehat secara optimal sehingga dapat meningkatkan status kesehatan dan kualitas hidupnya ( Khairuddin, 2008 ).

Dalam mencapai kesehatannya lansia perlu motivasi intrinsik dan motivasi ekstrinsik Motivasi intrinsik yaitu motivasi yang berfungsi tanpa rangsangan dari luar tetapi sudah dengan sendirinya terdorong untuk berbuat sesuatu misalnya dari dalam dirinya lansia itu sendiri, sedangkan motivasi ekstrinsik yaitu motivasi yang berfungsi karena adanya rangsangan dari luar seperti lingkungan, teman, keluarga, dan informasi. Informasi senam lansia diberikan oleh kader posyandu atau pemandu senam, informasi diharapkan dapat membantu dan memotivasi lansia untuk melakukan senam lansia, selain motivasi dari diri sendiri diharapkan juga dukungan dari keluarganya sendiri (Sugaray, 2012). 


\section{METODE}

Jenis penelitian ini menggunakan analisis deskriptif yang mempelajari dan menganalisis tentang hubungan dukungan keluarga terhadap motivasi lansia untuk mengikuti senam lansia di RW 02 keluarahan Kampung melayu Kecamatan Jatinegara. Desain penelitian yang digunakan adalah Cross sectional. Penelitian ini akan dilakukan di RW 02 kelurahan Kampung Melayu Kecamatan Jatinegara dan penelitian ini dilaksanakan pada bulan Juli 2018. Populasi dalam penelitian ini adalah 96 lansia di RW 02

\section{HASIL \& PEMBAHASAN}

Gambaran motivasi lansia di wilayah kecamatan Jatinegara berdasarkan hasil pengakuan dari responden adalah dengan kategori motivasi kurang dan motivasi baik. Bentuk dukungan yang diberikan oleh keluarga terdiri dari dukungan penilaian, dukungan instrumental, dukungan informasi dan dukungan emosional.

Tabel 1.

Distribusi Frekuensi Responden Berdasarkan Motivasi lansia

\begin{tabular}{c|l|l}
\hline Variabel & Jumlah & Pesentase \\
\hline & $(\mathbf{n = 9 6 )}$ & $(\mathbf{n = 9 6 )}$ \\
\hline Motivasi Lansia: & & \\
\hline 1. Kurang & 44 & 45,8 \\
\hline 2. Baik & 51 & 53,1 \\
\hline
\end{tabular}

Tabel 2

Distribusi Frekuensi Responden Berdasarkan Dukungan Penilaian, Dukungan Instrumental, Dukungan Informasi, Dukungan Emosional

\begin{tabular}{lcc}
\hline \multicolumn{1}{c}{ variabel } & Jumlah (n=96) & Persentase \\
\hline Dukungan penilaian & 53 & \\
Kurang & 43 & 52,2 \\
Baik & & 44,8 \\
Dukungan intrumental & 55 & 57,3 \\
Kurang & 41 & 42,7 \\
Baik & & \\
Dukungan informasi & 54 & 56,3 \\
Kurang & 42 & 43,8 \\
Baik & & \\
Dukungan emosi & 53 & 52,2 \\
Kurang & 43 & 44,8 \\
Baik & & \\
\hline
\end{tabular}

Dari tabel diatas Menunjukan sebagain besar lansia memiliki motivasi yang baik dalam mengikuti senam serta sebagian besar dukungan penilaian dukungan instrumental, dukungan informasi dan dukungan emosional yang diberikan oleh keluarga terhadap lansia masih kurang.

Hubungan dukungan keluarga dengan motivasi lansia dalam mengikuti senam lansia yang terjadi berupa dukungan penilaian, instumental, informasi dan emosional dapat dilihat pada tabel. 
Tabel 3

Hubungan dukungan keluarga dalam motivasi lansia mengikuti senam lansia di RW 02 Kelurahan Kampung Melayu Kecamatan Jatinegara

\begin{tabular}{|c|c|c|c|c|c|}
\hline \multirow[t]{2}{*}{ Dukungan } & \multicolumn{2}{|c|}{ Motivasi } & \multirow[t]{2}{*}{ total } & \multirow{2}{*}{$\begin{array}{c}\mathbf{P} \\
\text { value }\end{array}$} & \multirow[t]{2}{*}{ PR $(\mathrm{CI}=(95 \%)$} \\
\hline & $\begin{array}{c}\text { Kurang } \\
(\%)\end{array}$ & $\begin{array}{c}\text { Baik } \\
(\%)\end{array}$ & & & \\
\hline \multicolumn{6}{|c|}{ Dukungan Penilaian } \\
\hline Kurang & 58,5 & 51,5 & 100 & $\mathbf{0 , 0 1 4}$ & 1,890 \\
\hline Baik & 31 & 69 & 100 & & $(1,140-3,133)$ \\
\hline \multicolumn{6}{|c|}{ Dukungan Instumental } \\
\hline Kurang & 58,2 & 41,8 & 100 & 0,012 & 1,939 \\
\hline Baik & 30,0 & 70.0 & 100 & & $(1,149-3,274)$ \\
\hline \multicolumn{6}{|c|}{ Dukungan Informasi } \\
\hline Kurang & 59,3 & 40,7 & 100 & $\mathbf{0 , 0 0 7}$ & 2,025 \\
\hline Baik & 29,3 & 70,7 & 100 & & $(1,198-3,422)$ \\
\hline \multicolumn{6}{|l|}{ Dukungan emosi } \\
\hline Kurang & 60,4 & 39,6 & 100 & 0,004 & 2,113 \\
\hline Baik & 28,6 & 71,4 & 100 & & $(1,249-3,574)$ \\
\hline
\end{tabular}

Dari tabel diatas diperoleh bahwa, hubungan dukungan penilaian terhadap motivasi responden untuk mengikuti senam lansia diperoleh Nilai $P$ Value $=0,014$ dan prevalensi Ratio $(\mathrm{PR})=1,890$. Kesimpulan uji ada hubungan yang bermakan antara dukungan penilaian keluarga terhadap motivasi responden untuk mengikuti senam lansia. Responden yang mendapatkan dukungan penilanan dari keluarga yang kurang beresiko 2 kali untuk tidak termotivasi untuk mengikuti senam lansia.

Hubungan dukungan instumental keluarga terhadap motivasi responden untuk mengikuti senam lansia diperoleh hasil $P$ Value Nilai $P$ 0,012 $(<0,05)$, Prevalensi Ratio $(P R)=1,939$. Kesimpulan uji ada hubungan yang bermakna antara dukungan instrumental keluarga terhadap motivasi responden untuk mengikuti senam lansia. Responden yang kurang mendapatkan dukungan instrumental dari keluarga akan beresiko 2 kali memiliki motivasi yang kurang dalam mengikuti senam lansia dibandingkan dengan yang mendapatkan dukungan instrumental yang baik dari keluarga.

Hubungan dukungan informasi keluarga terhadap motivasi responden untuk mengikuti senam lansia diperoleh hasil $P$ Value $0,007(<0,05)$ Prevalensi Ratio $(\mathrm{PR})=2,025$. Kesimpulan uji ada hubungan yang bermakna antara dukungan informasi keluarga terhadap motivasi responden untuk mengikuti senam lansia. Responden yang kurang mendapatkan dukungan informasi dari keluarga beresiko 2 kali memiliki motivasi yang kurang untuk mengikuti senam lansia.

Hubungan dukungan emosional keluarga terhadap motivasi motivasi responden untuk mengikuti senam lansia diperoleh hasil Nilai $P$ value $=0,012(<\quad 0,05)$ revalensiRatio(PR $)=2,113$. kesimpulan uji ada hubungan yang bermakna antara dukungan emosional keluarga terhadap motivasi responden untuk mengikuti senam lansia. Responden yang kurang mendapatkan dukungan emosi dari keluarga akan berisko 2 kali mengalami motivasi yang kurang untuk mengikuti senam lansia. 
Motivasi adalah sejumlah proses yang bersifat internal atau eksternal bagi seorang individu yang menyebabkan timbulnya sikap antusiasme dan persistensi dalam hal melaksanakan kegiatan-kegiaan tertentu. Motivasi dipengaruhi oleh faktor instrinsik maupun ekstrinsik . Salah satu faktor instrinsik adalah dukungan keluarga. Dukungan keluarga adalah proses yang terjadi terus menerus disepanjang masa kehidupan manusia, dimana dukungan keluarga berfokus pada interaksi yang berlangsung dalam berbagai hubungan sosial sebagaimana yang dievaluasi oleh individu. Dukungan keluarga adalah sikap, tindakan dan penerimaan keluarga terhadap anggotanya. Anggota keluarga memandang bahwa orang yang bersifat mendukung selalu siap memberikan pertolongan dan bantuan jika diperlukan (Friedman,2013)

Dari hasil penelitian ini diketahui bahwa lansia sebagain besar memiliki motivasi yang baik dalam mengikuti senam lansia. Hasil penelitian ini sejalan dengan penelitian Anas Tamsuri (2016) hasil penelitian didapatkan $64 \%$ responden yang memiliki motivasi dengan kriteria baik dan penelitian Sri (2014). Dengan adanya motivasi yang baik akan meningkatkan kemampuan seorang individu dalam melakukan kegiatan atau aktivitas sehari - hari. Dimana motivasi merupakan upaya untuk menimbulkan rangsangan, dorongan ataupun pembangkit tenaga seseorang agar mau berbuat dan melaksanakan sesuatu, ( Maryam,2007).

Dukungan keluarga sebagai faktor ekstrinsik yang dapat mempengaruhi individu, dari hasil penelitian ini diperoleh bahwa 55,2\% lansia mendapatkan dukungan penilaian kategori kurang, 57,3\% lansia mendapat dukungan instrumental kategori kurang, 56,3\% mendapat dukungan informasi kurang dan 55,2\% lansia mendapat dukungan emosional kurang Untuk dukungan penilaian dari keluarga hasil penenlitian ini lebih rendah dibandingkan dengan penelitian yang dilakukan oleh Nova Satriana (2013) 70,6\%) yang memiliki dukungan penilaian yang kurang dan penelitian yang dilakukan oleh Afriani Mangasi (2013) $67,6 \%$ ) yang memiliki dukungan keluarga yang kurang. Dukungan penilaian adalah keluarga yang bertindak membimbing dan menengahi pemecahan masalah, sebagai sumber dan validator indentitas anggota keluarga diantaranya memberikan support, penghargaan, perhatian. Friedman (2012). Bentuk dukungan membantu lansia dalam membangun harga diri dan kompetensi untuk dapat menjalani kehidupan dengan baik, seseorang membutuhkan kemauan untuk memandang hidup sebagai sebuah harapan dan juga dibutuhkan pikiran yang positif dalam memandang setiap permasalahan yang mereka alami. Peran positif dari keluarga akan membuat lansia berfikir bahwa kehadirannya masih sangat berarti dan dibutuhkan dalam menjalankan kehidupan.

Dukungan instrumental adalah keluarga merupakan sumber pertolongan praktis dan konkrit, diantaranya adalah dalam hal kebutuhan keuangan, makan, minum dan istirahat. Friedman (2012). dari hasil penelitian ini diperoleh lansia yang mendapatkan dukungan instrumental 57,3\% mendapatkan dukungan kurang dari keluarga. Hasil penelitian ini bertolak belakang dengan penelitian yang 
dilakukan oleh penelitian Alnidi (2011), dalam penelitiannya mengatakan bahwa hampir sebagian besar dari responden $(53,2 \%)$ memberikan dukungan instrumental yang mendukung kepada lansia. Kondisi tersebut tentunya sangat berpengaruh terhadap kondisi kesehatan lansia terkait untuk melakukan kegiatan yang bertujuan untuk menjaga kebugaran tubuh lansia terutama dalam mengikuti kegiatan senam lansia.

Dukungan informasional adalah keluarga berfungsi sebagai pemberi informasi, dimana keluarga menjelaskan tentang pemberian saran, sugesti, informasi yang dapat digunakan mengungkapkan suatu masalah kepada lansia ( Friedman (2012). Dimna dukungan informasi inipun tak kalah penting dengan dukungan penilaian dan dukungan intrumental. Dimana setiap individu butuh informasi dalam bentuk apapun . apabila keluarga tidak dapt memberikan dukungan informasi maka lansia yang ada didalam keluarga merasa tersisihkan dan merasa diasingkan dari informasi yang ada didalam keluarga maupun informasi dari luar. Kondisi tersebut tentunya akan mengakibatkan masalah baik fisik maupun masalah psikis yang seharusnya dapat diatasi dan dicegah agar tidak terjadi. Dari hasil penelitian ini menunjukkan hanya 43,7 \% lansia mendapat dukungan informasi baik dari keluarganya. Hasil penelitian ini lebih rendah dari hasil penelitian yang dilakukan oleh Afriani Mangasi (2013) 63,2\% lansia memiliki dukungan informasi yang baik dari keluarganya. Dari hasil penenlitian ini banyak lansia yang kurang mendapat dukungan informasi Hal tersebut disebabkan oleh keluarga yang sibuk bekerja, kurang memperhatikan kondisi lansia, dan tidak tahu kebutuhan informasi untuk lansia karena kurangnya waktu untuk saling bercengkrama dengan anggota keluarga dan berpersepsi lansia tidak butuh informasi. Hal tersebut tentunya perlu dirubah, karena lansia adalah individu yang walauapun dengan keterbatasaanya akibat perubahan proses menua informasi seharusnya tetap harus diberikan oleh keluarga,sehingga lansaia menjadi lebih peduli dengan kesehatan dan kondisi fisiknya dan bisa mandiri tidak menjadi tergantung sepenuhnya kepada anggota keluarga yang lain.

Dukungan emosional adalah keluarga sebagai tempat yang aman dan damai untuk istirahat serta pemulihan dan membantu penguasaan terhadap emosi. Dukungan emosional meliputi dukungan yang diwujudkan dalam bentuk adanya kepercayaan dan perhatian. Dari hasil penelitian ini hanya 44,8\% lansia mendapatkan dukungan emosional yang baik. Hasil penelitian ini lebih rendah dari penelitian yang dilaksananakan oleh Afriani Mangasi (2013) 69,1\% lansia yang memiliki dukungan emosional yang baik. Pada penelitian ini terjadi diakibatkan karena keluarga kurang memperhatikan lansia karena sibuk dengan aktifitasnya masing-masing, keluarga jarang mendengarkan keluhan dari lansia karena keterbatasan waktu untuk berkumpul. Dari hasil penelitian inipun menunjukkan karena kurangnya dukungan emosi dari keluarga lansia beresiko 2 kali untuk tidak termotivasi melakukan senam lansia. Melalui hasil penelitian ini perlu dilakukan pembinaan keluarga dari berbagai pihak, terutama petugas 
kesehatan untuk dapat memberikan pendidikan dan melibatkan tanggung jawab kepada keluarga terhadap kesehatan pada lansia yang ada dikeluarganya. Tetap memberikan penghargaan , memberikan dukungan material, emosional sehingga lansia dapat sejahtera dan mandiri.

\section{KESIMPULAN DAN REKOMENDASI}

Dari hasil penenlitian ini dapat disimpulkan bahwa motivasi lansia untuk dapat mengikuti senam lansia sebagaian besar baik (64\%). Namun untuk dukungan keluarga terhadap lansiasebagain besar masih kurang , dimana diperoleh dukungan bahwa 55,2\% lansia mendapatkan dukungan penilaian kategori kurang, 57,3\% lansia mendapat dukungan instrumental kategori kurang, 56,3\% mendapat dukungan informasi kurang dan 55,2\% lansia mendapat dukungan emosional kurang. Dan lansia yang kurang mendapatkan dukungan penilaian, instrumental, informasi dan emosional berisiko 2 kali mempunyai motiasi yang kurang untuk mengikuti senam lansia.

Dengan hal tersebut disarankan kepada keluarga untuk dapat tetap memperhatikan kondisi lansia walaupun dalam kesibukan tetap memberikan waktu dan dukungan agar lansia mampu melakukan kegiatan sehari- hari terutama senam lansia, saran kepada petugas kesehatan untuk dapat memberikan pendidikan kesehatan kepada keluarga dan memberikan dorongan kepada keluarga untuk bertanggung jawab dan mau terlibat dalam perawatan lansia yang ada di keluarga sehingga lansia merasa dihargai dan bisa hidup sejahtera dan mandiri.

\section{REFERENSI}

1. Kushariyadi, Asuhan Keperawatan pada Klien Lanjut Usia. Jakarta, Salemba Medika. 2010

2. BPS, Jakarta Pusat, 2014. Statistik Pusat Tahun 2014. Jakarta Pusat ,2014

3. Komnas Lansia, Profil Penduduk Lanjut Usia 2009, Jakarta.2010,

4. Widianti,. Senam kesehatan. Yogyakarta. Naha medika, 2010

5. Indriana, Y. Gerontologi dan Progeria. Yogyakarta: Pustaka Pelajar,2012.

6. Paryanti, Hubungan antara pengetahuan lanjut usia tentang senam dengan keaktifan dalam mengikuti senam di posyandu desa ngargorejo ngemplang boyolali. Surakarta, FIK UMP. 2011.

7. Azizah, Keperawatan lanjut usia, Graha Ilmu, Yogyakarta, 2011

8. Handayani, D., Wahyuni. Hubungan Dukungan Keluarga dengan Kepatuhan Lansia dalam mengikuti Posyandu Lansia Jetis Desa Krajan Keacamatan Kabupaten Sukoharjo. Jurnal Stikes volume 9, 2012.

9. Khairuddin, Sosiologi keluarga. Yogyakarta: liberty. (2008).

10. Sugaray, Factor-faktor yang mempengaruhi motivasi lansia dalam melakukan senam lansia di upt pelayanan tresna wherda khusnul khotimah. Pekanbaru 2012.

11. Friedman..Keperawatan keluarga.Yogyakarta: Gosyen Publishing, 2012

12. Friedman . Buku Ajar Keperawatan keluarga : Riset, Teori, dan Praktek. Edisi ke-5. Jakarta: EGC, 2013

13. Akhmadi, .Permasalahan lanjut usia(Lansia). dari http://www.rajawana.com/artikel/kesehatan/326 permasalahan-lanjut-usia-lansia,html Diakses pada tanggal 12 Februari 2016. 
14. Maryam, Siti. "Menengenal Usia Lanjut dan Perawatannya”. Jakarta: Salemba Medika, 2008.

15. Novianti Faktor Faktor Yang Mempengaruhi Perilaku Lansia Dalam Mengikuti Senam Hipetensi Di Wilayah Kerja Puskesmas. Jurnal Keperawatan Silampari (JKS) Volume 1, No 2, Januari-Juni 2018.

16. Alnidi et all, Gambaran Keluarga Terhadap Pemanfaatan Posbindu Lansia Di Kelurahan Karasak Kota Bandung, (Skripsi). Fakultas Ilmu Keperawatan Universitas Padjadjaran, Bandung, Jawa Barat, 2011.

17. Febriani, Pengaruh Motivasi, Kompensasi serta Lingkungan Kerja Fisik terhadap Kinerja Karyawan Hotel The Niche Bali. E-Jurnal Manajemen Universitas Udayana, 2(5), 541-551, 2013.

18. Balitbang Kemenkes RI. Riset Kesehatan Dasar; RISKESDAS. Jakarta: 2013.

19. Boedhi, Darmojo, R..Buku Ajar Geriatic (IlmuKesehatanLanjutUsia) Edisi ke - 4.Jakarta :BalaiPenerbit FKUI.2011

20. Dharma Metodologi Penelitian keperawatan. Jakarta :CV. Trans Info Media. 2011

21. Hastono, Statistik Kesehatan. Edisi VI. Jakarta : PT. Raja Grafindo Persada. 2011

22. Nursalam, Konsep dan Penerapan Metodologi Penelitian Ilmu Keperawatan Pedoman Skripsi, Tesis dan Instrumen Penelitian Keperawatan. Jakarta: Salemba Medika. 2008 